\title{
THE HONOURABLE WILLIAM LEGH WALSH
}

\author{
G. H. Srran
}

The period from January 28, 1857 to January 13; 1938. is the spa! $、 !$ titr lifetime of William Legh Walah, succesuively, a most distinguished courte! .. Canadian courts (1904-1912), a Judge of the Supreme Court of Alinert: (1912-1931), Chancellor of the Anglican Diocese of Calgary (1927.19;1), and Lieutenant-Governor of Alberta (1931-1936). His lifespan saw his native Canada develop by slow stages from the colonial status it cccupied at the dare of his birth in 1857 into a fully autonomous naxior: which in recent years is achieving the full deveiopment of its potencialities.

The ideal development of body and mind-the mens sana in corpore sano -is exemplified in the careet of "Daddy Walsh" as he came to be lovingly known to a host of friends throughout his long life. His call, straight, alert and manly figure, his bright eye and elastic step even when well pase thr threescore year mark are characteristics well remembered by all who knew hur in his later years in Edmonton, as weli as his great dignity, his keen sense ct. humor and his intense interest in all public affairs, religious and political.

During his boyhood and young manhood in Simcoe, Ontario, he lived the normal, typical life of a youth in the last decades of the nineteenth rentus: He was a member of the Simcoe cricket team, a game which in those days had a tremendous following for both spectators and players; he also was a better than average tennis player, a game which fortunately has retained among the youth of today some, though not all, of its popularity. He was also throughout the greater part of his life an ardent curler and, as intensely interested in the rugged game of lacrosse as we are today in that equally rugged game of rugby football.

In later years, he maincained his naturally fine physique by an ardent adherence to the game of golf, which he took up soon after. going to Calgary. The way in which he became interested in the game is an amusing story The late Judge and a friend of his, Bill Georgeson, a well-known Calgatian, met one evening in 1912 at the Ranchenen's Club. Neither had previouslv had any experience with golf but, this nothwithstanding, they decided on a contest for a wager of five dollars; this a gratified Judge ultimately pocketed bossting thereafter of never having lost a golf game. His love of the gamic persisted throughout his life. He was a charter member of the Calgar, Golf and Country Club, its president in 1919.20, a distinction he shares with many distinguished men. He donated the handsome Walsh Trophy in 1924 which in Alberta golf circles is scill a prizend trophy.

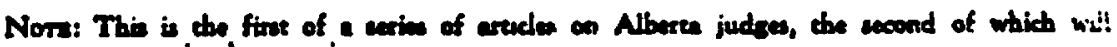
eppent in the vext ineue.

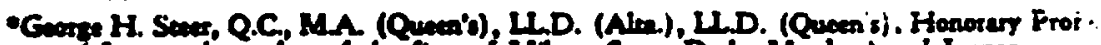
coe of Law, and member of the firm of Miler, Stan, Drde, Mereland and Layeon 
Wijilians i-egh Walsh iefr Simcoe in 1874 at the age of seventeen to become an articied student-at-law at Ontario's Oaguode Hall in Toronto. It is inreresting to take out minds back to the public and secondary schools of those days supplemented for the lawyer by a system of legal education which had not then actained its high degree of present-day excellence; one wonders whether the development of so many first rate intellects under this system, such as that of the subject of this article, was not due to the degree of selfreliance inculicated by the subjects and methods of study in the lower schocis, and again upon the emphasis upon personal application in professional sehools. The late W. N. Tilley, distinguiated Canndian counsel, always maintained that the system of service under articles was the best method by which a young man should begin his mastery of the law. One of the men of great intellectual power whom the system produced was Walsh J, who became. well known throughout $C_{a n a d a}$ as an able counsel and gifred judge, especially in the trial of eriminal cases.

He was admitted to the Law Society of Upper Canada as a solicitor in 1879 and as a barrister in 1880. Returning to Simeoe, he became a junior parmer in the firm of Ansiey, Slaght and Walsh. The quality of the man is shown by the fact that within two years of his call he became a partner ot that great Canadian legal and political figure D'Alton McCarchy practising at Orangeville, Ontario, the firm name being McCarthy, Walsh and Hughson. With that firm he remained until 1890 from which year until 1910 his name appears as practising at Orangeville either alone or in partmership with a brother-in-law, 1. N. Fish, under the tirm name of Walsh and Fish. In fact. in 1900, ar the age of 43, he opened a practice at Dawson City in the Yukon Territory two years after the opening of the Klondike gold rush. Perhaps he intended to return to Orangeville, but the call of the West-fortunately for the West-became toc strong for him: as for so many others of us frem Eastern Canada, it was;

Sor by Eastern window only

When covlughe comes, comen in the liplut.

In isont the oun ctimbe slow how dowly

But Westward lowk, the land is bright.

in 1903 he was appointed a King's Counsel and from this date on his name appears in the reports of cases tried as counsel in the Yukon and North.West Territories. It was as a meinber of the bar of the North West Territuries that in 1904 he opened the last phase of his career as a distinguished counsei in partmerahip with M. S. McCarthy, a nephew of his former Otangeville partner, who came West in 1904.

ite also played a conspicuous parr in the formation of the Law Sociery of Alberta, The first Ordinance respecting the legal profession in the NorthWest Tetritories had been passed by the Lieutenant-Governor-in-Councih, December 18th, 1885. From that time until the incorporation of the Law Society of the North-West Territories by Ordinance 21 of September 19, 1898, the practice of law in the Territories was controlled by the Government which collected fees from advocates, as they were called, who were entitled to practise in the Territorial Courts. Then, in Seprember 1898, the Law Society 
or the North. West 'Territories was incorporated ov ordinan.... In the rnl!: of this Law Socrety of the Territories listing advocates entideo tn practssc. the name William Legh Walsh appears as Number 217. His name is precede: and followed on that role by those of many great lawyers who like him achieved distinction in their professien

In 1907, the Law Suciery of Alberta was incorporated and Walsh Q.:... was a charter member because he was one of "the persons who on the coming into force of this Act are encolled as advocates of the North West Territories and are resident in the Province of Alberta." From this time on the advocates were known as Barristers and Solicizors. He was one of the first Benchers of the Society and continued activity in this office untii Aprii 3.2. . 1912 when he was appointed to the bench of the Supreme Court a! Alberta.

Prior to his appointment to the Bench, his last major assignment as counsel was presenting the Province's case in the celebrated case of The Kiing v. The Royal Bank of Conoda' which in its stages through the courts still makes interesting reading, political as well as legal.

As a member of the Bench. Mr. Justicc Walsh was a model judige. His career was characterized by Bacon's admonition "to walk in the light that me1. might see that no pasticulas tum or end led him but a genera! rule". He w'xs not the over-speaking Judge whom Bacon has described as "ne well-runtd cymbal". He had the grace to sit in ssience ever. for days at a time ne: attempting "furst to find that which be might have heard in due time from the bar". Never did he artempt so show quickness or conceit in cutting off evidener or counsel too short, or to prevent information by questions thought pertinent. He possessed in an eminent degree the qualities which Bacon has described as the ideals for a Judge "to direet the evidence; to moderate length. repetition or impertinency of speech; to recapitulate, select and collate the nisteriai points of that which has been said; and to give the rule or sentenec".

Lauvers who were privileged to appear before him will agree that the words just quoted contain a just description of the conduct of $W_{2}$ lsh J. on the lench. and many of us recall the very kindly and sympathetuc attitude displayed br him in the voung counsel first finding lis fee: in Court and especially wiss this :." when he was giving his judgment against you.

The late Judge always considered that of the many cases over the tria: . . which he presided the most dramatic was the Picariello-Lassandro murdr. trial. The two accused Emilio Picariello and Mrs. Florence Lassandra wrsh tried and ennvicted of the murder of Provincial Constable Steve C. Lawson z: Coleman, Alberta. ${ }^{2}$ Leading respectively for the Crown and the detience wer: rwo of Alberta's most distinguished counsel, A. A. MrGillivtay, K.C. and i. MeKunley Cameron. K.C. MeKinley Cameron was led in this Appeal by one of our great Canadian councel Aime Geoffrion, K.C. So far as the case, beats :the judieiai eapacity of Walst J. is is interesting to read the Judpasent a! Mignaulr J. who said:

'(19)01, 3 Alta. L.R 4RD, 4 Ale. LR. 249, 3 W.W.R. 954

2:1923: 1 W.W.R. 645: Supreme Coure of Cined, [1973j i W.W.R. :4.": 


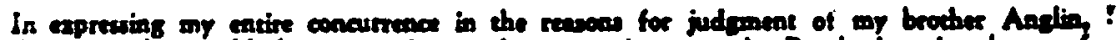

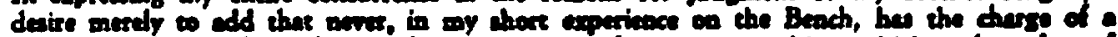
trinl Judre been cubjected to a closer caruting and a more varching criticing then that of

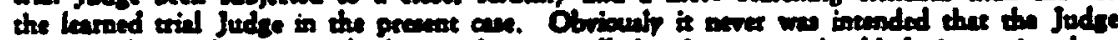

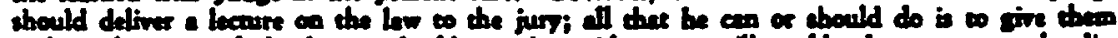
such explenation of the len epplienble to the evidence as will eneble them to property dis.

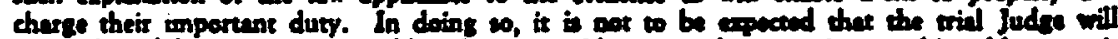

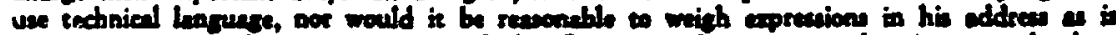

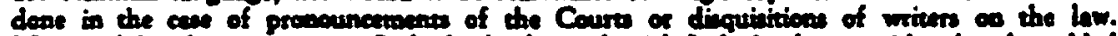

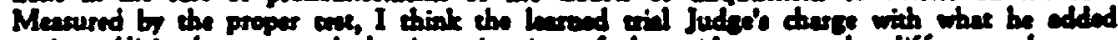

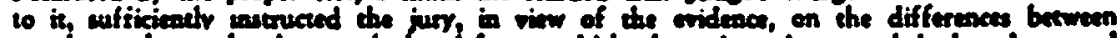

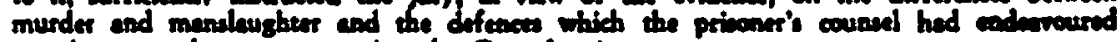
to subsuntare by coubserenting the Crowis wisnewe.

Mr. Justice Walsh's interest in politics and public affairs commenced prior to his coming Wese. He was elected Mayor of Otangeville for three terms and was a Conservative Candidate in the Federal Election of 1895 in the Cardwell sonstituencv. This was the Manitobe School Election which, on the iseve of The Remedial Bill defeated the government of the suecessors of Sir John A. MacDonald and swept Sir Wilfred Laurier into power, dashing the hopes for 2 political career of the 38-year-old Conservacive candidate for Candwell.

He was defeated for the Mayoralty of Dawnon City and. in what is now an amusing story he lost the Federal nomination for the Dawson City riding in a Federal Bv.Election held in 1902. Recognized as the leading counsel in the Yukon Tetritory and a citizen of great popularity, it seemed certain that W'alsh Q.C. was assured of the Conservarive nomination. It is related that at a meeting of the Conservative executive, a few friends of the late Joe Clarke (afterwards in 1919, 1920, 1935, 1936 and 1937 Mayor of Edmonton and the moving spirit behind the Clarke Sadium project) attended and suggeared an open nominating convention to be atrended by all political parties. Despice the cognomen of "Foxy Grandpa" which had been recked on him and stuck throughout his life, the prospective Conservative candidate and his advisers fell for the suggestion. Then, as the story goes, Joe and his friends packed the convention and secured the nomination for Clarke.

He made one more attempt to give to the province the benefit of his powers. He was a candidate for the Legislature in 1906 in a byelection unsuccessfully contesting the vacancv in the riding of Gleichen, occasioned by the elevation to the bench of the bre Mr. Justice Stuntr for many years an eminent Alberta Appeal Court Judge and also for many years the Chancellor of the Univerzity of Alberta. In 1931 Walsh J. retired from the Bench to become the Lieutenant Governor of Alberta, an appointment which was the culmination of an interest in public attairs which characterized him throughout his life. He held the office of Lieutenant Governor until 1936 and mainenined a keen interest in the public affairs of Alberta particularly the legislation introduced by the Government which resulted in his succescos, Lieutenant-Governor Bowen, reserving for tre signification of the Goverwor General's pleanure three Bills pased by the Legislature in the third seacion of the year 1937. The Governor in Council. pursuant to Section 55 of the Supreme Court Act, referred these Bills to the Supreme Court of Canada for its opinion as to their constitucional validity. The opinion of the Court resulted in the disallowance of all three Bills 
From his retirement in Victoria, B.C.. the late judge wote tor suoina. tion a reasoned opinion adverse to the power of the Province to enace T $T$ i.c. Credit of Alberta Regulation Act. The opinion is noteworthy as indicating she apprnach of his mind tn such public questions. He wrote:

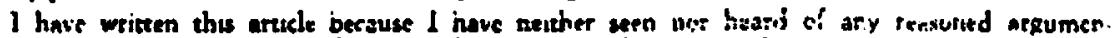

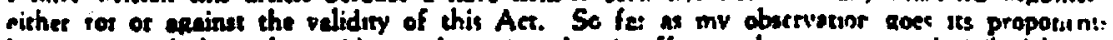
have contented themselves wich sumply seying that it affeces unly property an.i civil tigh:s ir the provinee, and so it is quite valid, while its oppenemus simpily soy that is it benicirs.s legulation end aherefore ulers vires of the province and boeh ades leave it at thas:

This legialacion and to diallowapee are matuen of geave public concern. It $\mathrm{s}$ in the publis

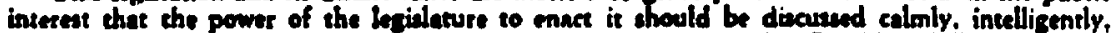
and without prejudies. I have pat forward the very strong viow that I hold as fully and clearly as I am able to, and I hope quite ditpessionetely thet comecne who holds the other verw vill do the seme.

Honored by his fellow cirizens to a degree thar talis to only ten mes, death. came to William Legh Walsh at Vietoria, January 13, 1938 in the 8!st yeas of his life. To the gratification of his fellow Albertans he had choser Calgarv and Alberta. the scene of his distinguished labors as his burial place. Foi. lowing the simple and profoundly moving funeral service in the Anglican Pro.Cathedrai of the Redeemer, he was buried within sight of the magnificent and awe-inspiring panorama of mountains and fonthilis which is Cil-ari: greatest natutal heritage.

Under the derk and atariy sky

Dig the grave and let me lise

Gladiv I lived and I pladly dir

And 1 by me down woth a wi::

Thus be the verne you grave for n.e Here the lies there he longed so bo

Home is the seilor, home frem the (k), And the hunter home from the hill 